\title{
Micropalaeontology reveals the source of building materials for a defensive earthwork (English Civil War?) at Wallingford Castle, Oxfordshire
}

\author{
IAN P. WILKINSON ${ }^{1}$, ALISON TASKER ${ }^{2}$, ANTHONY GOULDWELL ${ }^{3}$, MARK WILLIAMS ${ }^{2, *}$, MATT EDGEWORTH ${ }^{3}$, \\ JAN ZALASIEWICZ ${ }^{2}$ \& NEIL CHRISTIE ${ }^{3}$ \\ ${ }^{1}$ British Geological Survey, Keyworth, Nottingham NG12 5GG, UK \\ ${ }^{2}$ Department of Geology, University of Leicester, Leicester LE1 7RH, UK \\ ${ }^{3}$ School of Archaeology and Ancient History, University of Leicester, Leicester LE1 7RH, UK \\ *Corresponding author (e-mail: mri@le.ac.uk)
}

\begin{abstract}
Microfossils recovered from sediment used to construct a putative English Civil War defensive bastion at Wallingford Castle, south Oxfordshire, provide a biostratigraphical age of Cretaceous (earliest Cenomanian) basal M. mantelli Biozone. The rock used in the buttress - which may have housed a gun emplacement - can thus be tracked to the Glauconitic Marl Member, base of the West Melbury Marly Chalk Formation. A supply of this rock is available on the castle site or to the east of the River Thames near Crowmarsh Gifford. Microfossils provide a unique means to provenance construction materials used at the Wallingford site. While serendipity may have been the chief cause for use of the Glauconitic Marl, when compacted, it forms a strong, almost 'road base'-like foundation that was clearly of use for constructing defensive works. Indeed, use of the Glauconitic Marl was widespread in the area for agricultural purposes and its properties may have been well-known locally. J. Micropalaeontol. 29(1): 87-92, May 2010.
\end{abstract}

KEYWORDS: Wallingford, Cretaceous, provenance, foraminifera, ostracods

\section{INTRODUCTION}

Microfossils have been recovered from a range of archaeological and historical remains including building materials (e.g. Wilkinson et al., 2008), art and ceramics (e.g. Perch-Nielsen, 1973; Quinn \& Day, 2007). The microfossil technique has wide 'forensic' application as even very small samples of rock (tens of grams) can yield hundreds of fossil specimens. The technique can be used to provenance building materials from classical contexts through to the present (e.g. Wilkinson et al., 2008). Here we apply techniques of microfossil biostratigraphy to establish the age of materials used in the construction of an enigmatic (English Civil War?) defensive buttress at Wallingford Castle in south Oxfordshire, a feature excavated as part of a major archaeological programme at the town - the Wallingford Burh to Borough Research Project.

The town of Wallingford lies adjacent to the River Thames to the west of London. Although the town has its origins in Saxon times, the history of the area (see Airs et al., 1975) suggests that the ford, attested to in the town's name, has been in use since at least the Bronze Age. Finds of Roman coins are known from the general area, and an Anglo-Saxon cemetery dating from the fifth to sixth century AD lies to the southwest of the town. In the late ninth century, as part of a wider strategy to counter the Danish threat, ramparts were raised by the army of King Alfred the Great around the town. After the Norman invasion a castle was built in Wallingford's northeastern corner in the late eleventh century. Further banks and ditches were created around the castle, thereby obscuring the line of the nearby section of the earlier town rampart, perhaps during the Anarchy of 1139-1153 when Stephen and Matilda were at war, or when the castle was extended in the thirteenth century. The castle's last major role was during the First English Civil War, the last gasp of which came with the Royalist surrender on 27 July 1646, after a siege of 65 days by Parliamentary forces.
Castle Meadows now contain the extensive surviving earthworks of the once magnificent Castle, demolished after the Civil War. Figure 1 shows the location of the castle earthworks in relation to the wider town and recent archaeological excavations (the trench under discussion here is marked as ' 4 ' on the map). A resistivity and magnetometer survey in April 2008 covered the northern part of the castle ramparts and the adjacent low-lying alluvial-deposits bordering the west bank of the Thames (Fig. 2), all just outside the outer moat of the castle. Among other features, the survey revealed an area ('bastion') projecting northwards from the castle ramparts to the west of a larger such promontory popularly referred to as 'the Civil War bastion', although this latter feature is undated. It is the material from the newly identified bastion that we have analysed using micropalaeontological techniques to establish its provenance.

\section{ARCHAEOLOGICAL CONTEXT OF THE BASTION}

A trench was excavated across the platform of the bastion during the summer of 2008 (http://www2.le.ac.uk/projects/wallingford_dig_2008). Figure 2 shows the location of the trench in relation to the results obtained from resistivity survey. The partially excavated platform was surfaced with light, variably olive, grey, weakly cemented sandy silt, overlying a sandy gravel preparation layer. Surrounding the platform was a large artificial depression, now mostly filled in, and thought to be a defensive ditch (though only the near side of the ditch has been revealed through excavation). The top of the platform created a level floor with some sandy preparation below. The material collected for microfossil examination was from this platform surfacing, which was itself buried under a shallow layer of topsoil.

Apart from tree-root holes and rabbit burrows, no features were found cutting the surface of the platform. Box sections 


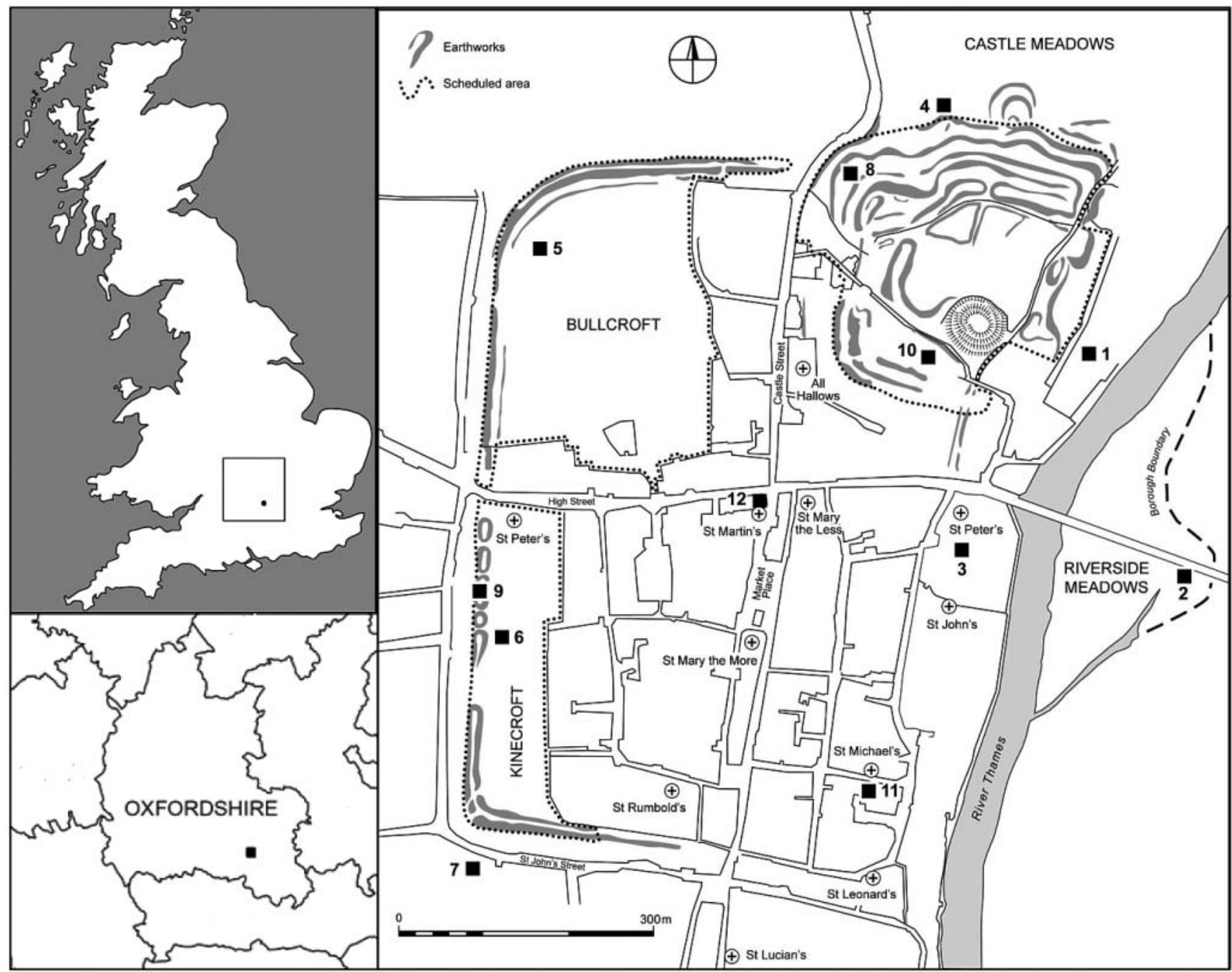

Fig. 1. Map of Wallingford showing the location of trench 1 in the bastion (archaeological locality '4' on the map) in Castle Meadows. (Drawn by Mike Rouillard.) Inset map shows the position of Wallingford in southern England.

were cut through the platform along the northern and eastern sides of the trench, revealing it to be about $0.5 \mathrm{~m}$ in depth and clearly of artificial construction. Beneath both the platform and the base of the ditch was a uniform layer of dark brown sandy loam containing medieval pottery (Fig. 3). This probably represents 'made ground' which may have been formed by up-cast from the digging of the outer moat of the castle during the medieval period.

Finds overlying the layer sampled for microfossils were mixed, of seventeenth- to nineteenth-century date with a number of fragments of clay pipes from the earlier to middle part of this range. Finds of pottery from the layer underlying the platform were dated as medieval (twelfth-fourteenth century). If the platform is taken to have served a military function, which seems plausible, then that is assumed to relate to the Civil War siege already mentioned. Interpretation of the levelling layer is speculative; but a level defensive platform, perhaps a gunnery position, would make sense. Strategically this 'bastion' fits topographically with that to the east (Fig. 1), and with features of similar appearance detected in the 2009 geophysical survey to the west, towards the town's north gate, a focus of assault during the Civil War.

Sampling of the bastion construction material was for routine analysis to investigate the presence of any inclusions such as carbonized cereals, wood charcoal, molluscs, bone fragments, etc. A two-litre pilot sub-sample was washed-over and floated (Kenward et al., 1980) and the residue sifted and allowed to dry before examination under stereoscopic zoom magnification and fossils picked out. Much of the matrix failed to disaggregate, and prolonged soaking in water and then hydrogen peroxide was used.

Small quantities of bone, molluscs, a trace of wood charcoal, a few worm ova and insect parts, molluscs and seeds were recovered. Normally from this type of site uncharred decomposable organic remains such as seeds and insects would be dismissed as intrusive. Given the cementation, it seems quite possible that at least some of these finds were trapped at the time of deposition of the sediment. The seeds and small fruits were fragile, but identifications were achieved using published illustrations (e.g. Cappers et al., 2006) and the botanical reference 


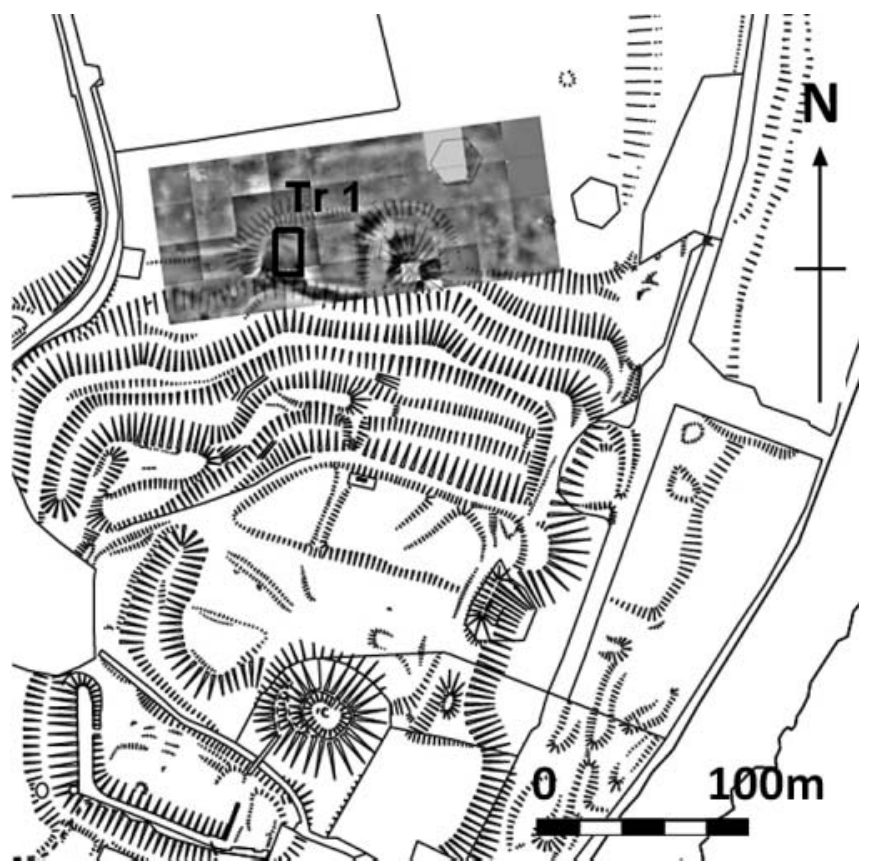

Fig. 2. Map of the northern part of Castle Meadows, showing earthworks and resistivity survey results. The position of the trench from which material for microfossil analysis was recovered is shown as ' $T r 1$ '.

collection in the School of Archaeology and Ancient History, University of Leicester. Species identified include: hazel nut, Corylus avellana L.; unidentified thistle, cf. Cirsium sp.; black nightshade, Solanum nigrum L.; fat-hen, Chenopodium album L.; poppy, Papaver sp.; and unidentified dock, Rumex sp. All were single finds except for fat-hen which was represented by three seeds.

The presence of seeds and fruits may indicate summer or autumn as the time of year when the sediment was laid down. Although hazel ripens in late August, it can be stored well beyond then for later consumption. The other species are ruderals and weeds so their occurrence should be natural.

\section{BIOSTRATIGRAPHICAL AGE OF SEDIMENT FROM THE BASTION}

Material from the platform was examined further for its microfossil-content in an attempt to provenance its source. The sediment sample from the bastion contained a rich microfossil assemblage of ostracods and foraminifera (Pl. 1; Appendix A). The hyaline and agglutinated benthic foraminifera indicate the sediment sample to be of Cretaceous, Cenomanian age (Fig. 4). Gavelinella baltica, G. intermedia, G. cenomanica and Hagenowina advena first evolved at the base of the Cenomanian and ranged throughout that stage. Hagenowina anglica became extinct in the $T$. costatus macrofaunal Subzone (basal $M$. rhotomagense macrofaunal Biozone) in the mid-Cenomanian. The stratigraphically restricted index species Flourensina intermedia is confined to foraminiferal Biozone BGS1 (equivalent to the $N$. carcitanense macrofaunal Subzone, basal M. mantelli Biozone). It was accompanied by a single fragment tentatively assigned to Bulbophragmium aequale cf. aequale, which supported this age determination.
A number of the ostracod species present (e.g. Schuleridea jonesiana, Cytherella ovata, Bairdoppilata pseudoseptentrionalis, Homocythere harrisiana, Neocythere vanveenae) are biostratigraphically long-ranging taxa of mid-Albian to midCenomanian age. However, others have a more restricted temporal distribution and support the age assignment established by the foraminifera. Cythereis hirsuta and $C$. thoernensis are known to occur in the Albian in France, but in the UK are found only in the uppermost Albian (perinflatum macrofaunal Biozone) and were more common in the lower Cenomanian. Neocythere steghausi first appeared in the Albian, but its extinction in the basal part of the $N$. carcitanense Subzone of the $M$. mantelli macrofaunal Biozone was an important bioevent and useful in dating the sediment from Wallingford Castle.

\section{PROVENANCE OF THE BASTION MATERIAL}

Cenomanian age geological deposits in the neighbourhood of Wallingford comprise the West Melbury Chalk Formation, including the Glauconitic Marl Member at its base (Fig. 4). The Castle site is located on the Glauconitic Marl and materials used to construct the platform may have been quarried on site or more likely perhaps - to the east of the river where the Glauconitic Marl and West Melbury Chalk form an extensive outcrop in the Crowmarsh Gifford area. However, the Glauconitic Marl is obscured beneath more recent superficial deposits (Summertown-Radley Sand and Gravel Member, Northmoor Sand and Gravel Member and the river alluvium) in the Wallingford area, so that quarrying would have been required. The only place shown on the geological map for this area where superficial deposits do not cover the Glauconitic Marl is to the north of Wallingford Castle (approximately National Grid Reference SU 608 905).

Although the precise function of the bastion remains uncertain, its stratigraphical context supports attribution to activity during the English Civil War in the mid-seventeenth century when the castle was besieged, captured and subsequently destroyed by Parliamentary forces. During this conflict the defenders of the castle would have needed a reliable and nearby source of sediment to construct durable defensive platforms, some of which may have been used as gun emplacements. The Royalist occupiers of Wallingford Castle were fortunate that outcrops of the Glauconitic Marl were available nearby and material could have been ferried to the construction site fairly easily. When compacted, the Glauconitic Marl forms a durable, almost 'road base'-like medium, making it eminently suitable for defensive works. However, the work of the Royalist builders was ultimately to no avail, as the castle fell to Parliamentary forces. Indeed, whatever military advantage was intended through construction of the bastion, there is no clear archaeological evidence that it actually played a part in any military action.

Subsequently, in the 2009 excavation season, more marly deposits used in construction were identified (http://wallingforddig.pbworks.com/): first extensively capping an embankment set back from the original site in Castle Meadows; and secondly on the School Playing Field site on the west side of the northsouth-running Castle Street, just north of the town ramparts, but here to a much greater thickness of at least $1.5 \mathrm{~m}$, apparently used for levelling uneven ground. The extent of medieval and post-medieval usage of the Glauconitic Marl Member may 


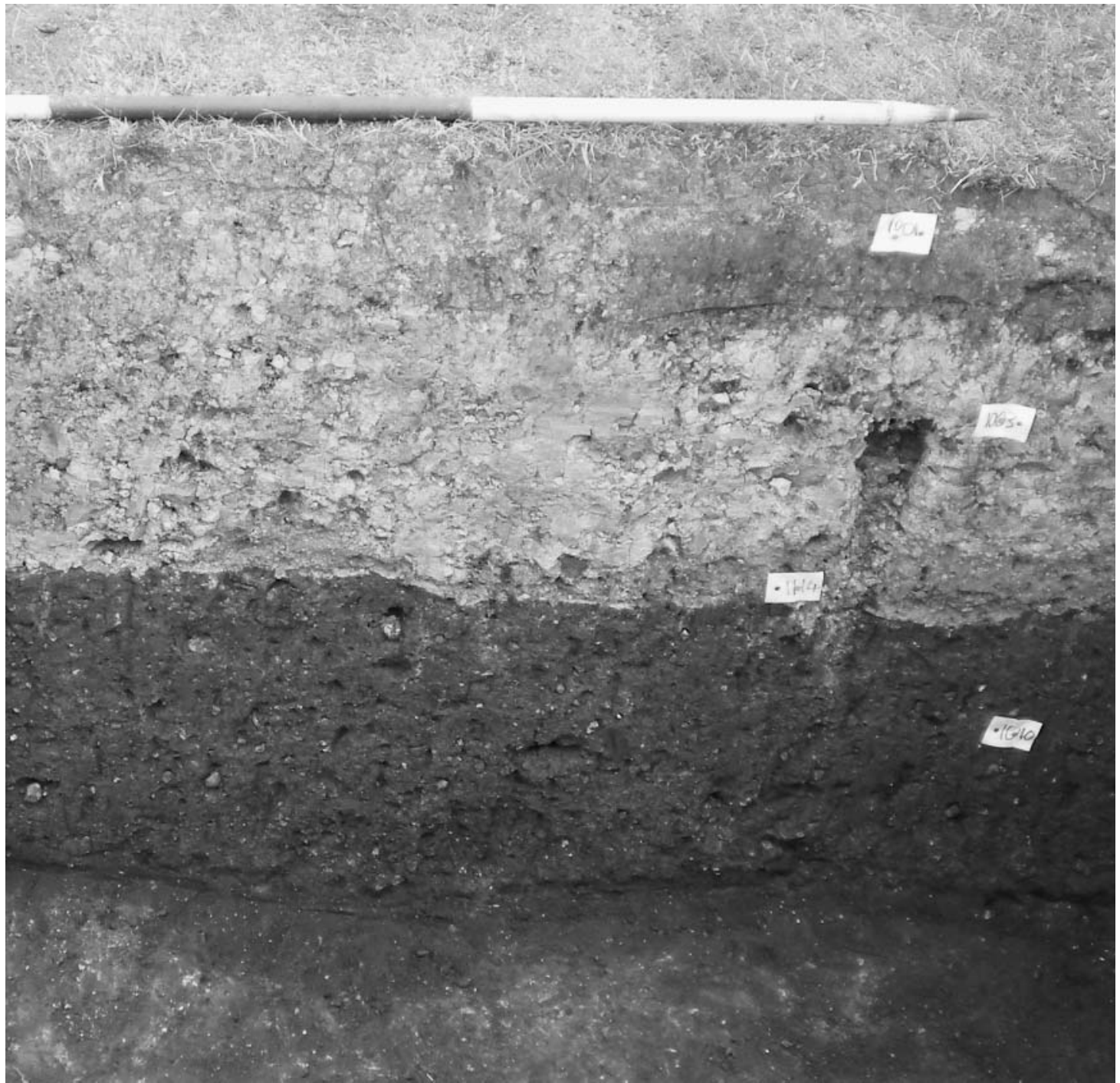

Fig. 3. Vertical section through the platform material (white colour) beneath a disturbed topsoil and overlying a uniform sandy loam layer of medieval date. Labels indicate archaeological context numbers. Scale bar $1 \mathrm{~m}$.

therefore have been much more substantial than the original discovery suggests, and may be illuminated by further investigation.

\section{CONCLUSIONS}

Microfossils identify the geological provenance of building materials used in the construction of a putative Civil War bastion at Wallingford Castle, south Oxfordshire. A ready supply of this material, the Glauconitic Marl Member of the West Melbury Marly Chalk Formation, was used widely in the area for agriculture and its properties may have been wellknown locally. The microfossil technique used here has great potential for establishing the provenance of a range of building materials from classical to early modern contexts.

\section{ACKNOWLEGEMENTS}

Excavations were conducted in Wallingford, south Oxfordshire, in the summer of 2008 as part of the Wallingford Burh to
Borough Research Project run from the Universities of Exeter, Leicester and Oxford supported by an Arts and Humanities Research Council grant. This followed and accompanied continuing survey in the town and immediate environs. The authors thank the Wallingford Burh to Borough Research Project for access to samples and help with excavation records. I.P.W. publishes with permission of the Director of the British Geological Survey (NERC).

\section{Manuscript received 8 October 2009 Manuscript accepted 23 January 2010}

\section{APPENDIX A}

The material used to construct the Wallingford Castle bastion contained fragments of echinoid spines, bivalve molluscs (including occasional Inoceramus) and very rare fish. Biostratigraphically significant taxa are mentioned in the text, but a full list of the calcareous microfossils recorded is given below. 


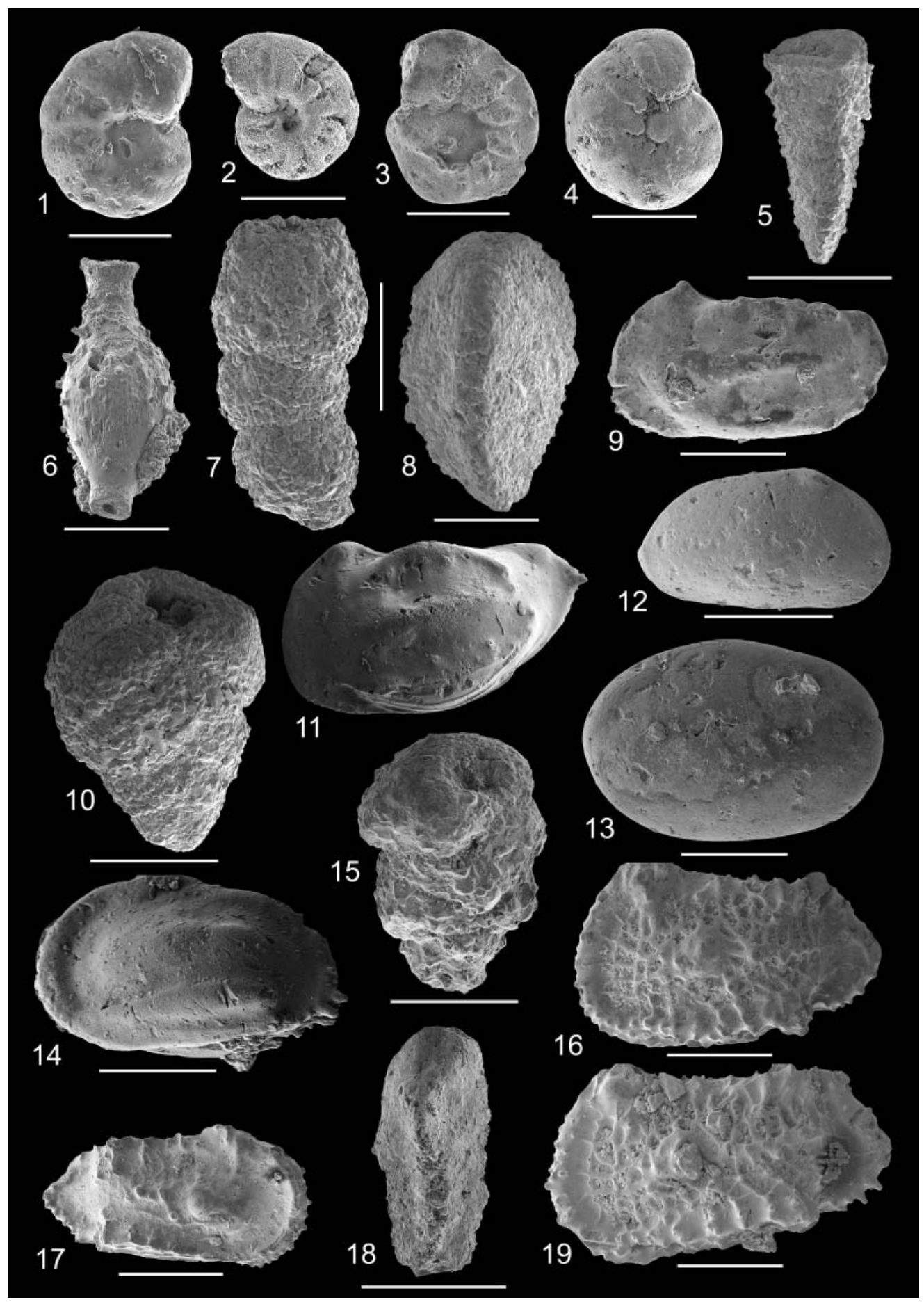

Explanation of Plate 1.

figs 1-19. Specimens from the building material (trench 1) of the bastion at Wallingford Castle: 1-8, 10, 15, 18, representative foraminifera; 9, 11-14, 16-17, 19, representative ostracods. All specimens are held in the biostratigraphical collections of the British Geological Survey, Nottingham, under the symbol 'MPK'. Measurements for scale bar are: $300 \mu \mathrm{m}$ on all images; except 7, 10, 12 and $15=500 \mu \mathrm{m}$; and 5 and $18=1 \mathrm{~mm}$. fig. 1 . Gavelinella intermedia ventral view. MPK13847. fig. 2. Gavelinella baltica ventral view. MPK13848. fig. 3. Gavelinella cenomanica ventral view. MPK13849. fig. 4. Gavelinella intermedia dorsal view. MPK13850. fig. 5. Marssonella ozawai lateral view. MPK13851. fig. 6. Ramulina sp. side view. MPK13852. fig. 7. Bulbophragmium aequale cf. aequale (fragment) side view. MPK13853. fig. 8. Tritaxia pyramidata side view. MPK13854. fig. 9. Homocythere harrisiana left lateral view. MPK13855. fig. 10. Hagenowina anglica side view. MPK13856. fig. 11. Protocythere lineata striata left lateral view. MPK13857. fig. 12. Schuleridea jonesiana right lateral view. MPK13858. fig. 13. Cytherella ovata right lateral view. MPK13859. fig. 14. Cornicythereis larivourensis left lateral view. MPK13860. fig. 15. Flourensina intermedia side view. MPK13861. fig. 16. Cythereis hirsuta left lateral view. MPK13862. fig. 17. Cythereis (Rehacythereis) luermannae luermannae right lateral view. MPK13863. fig. 18. Tritaxia macfadyeni side view. MPK13864. fig. 19. Cythereis thoernensis left lateral view. MPK13865. 

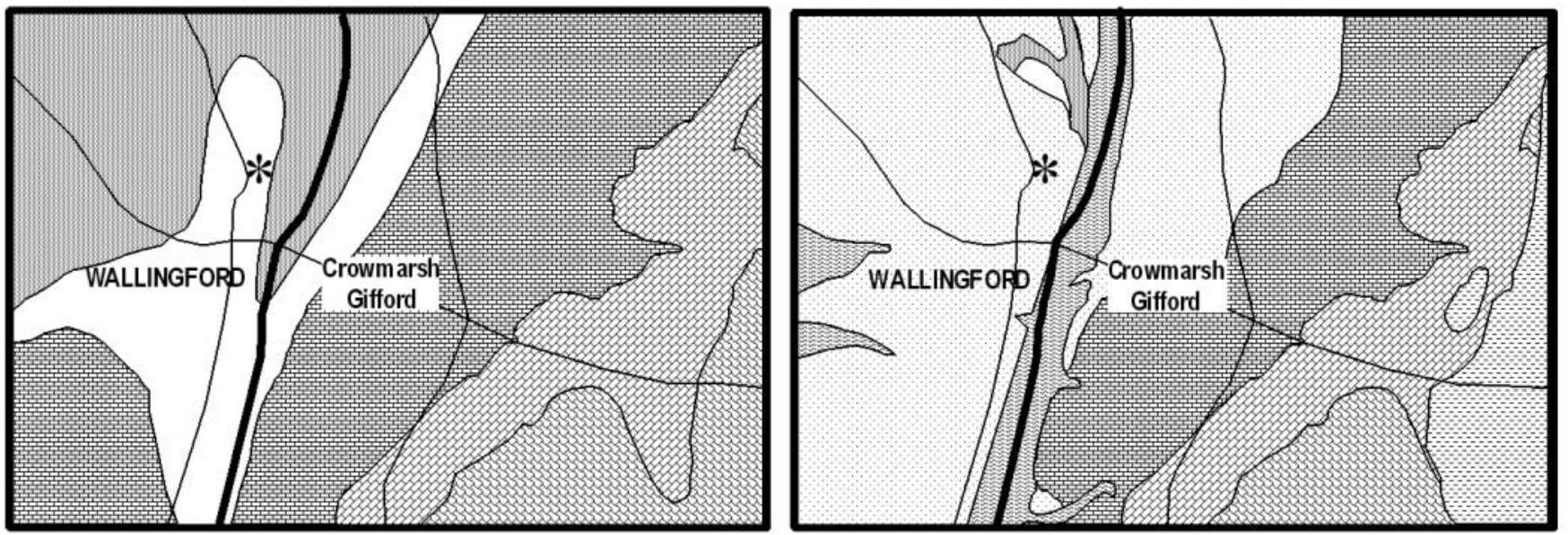

Bedrock

\begin{tabular}{|c|l|}
\hline TURONIAN & Holywell Nodular Chalk Formation \\
\hline \multirow{3}{*}{ CENOMANIAN } & Zig Zag Chalk Formation \\
& West Melbury Marly Chalk Fm. \\
\hline ALBIAN & Glauconitic Marl Member \\
\hline
\end{tabular}

Superficial (Quaternary) deposits

\begin{tabular}{|l|l|}
\hline Thames Valley Formation \\
\hline & Alluvium \\
\hline
\end{tabular}
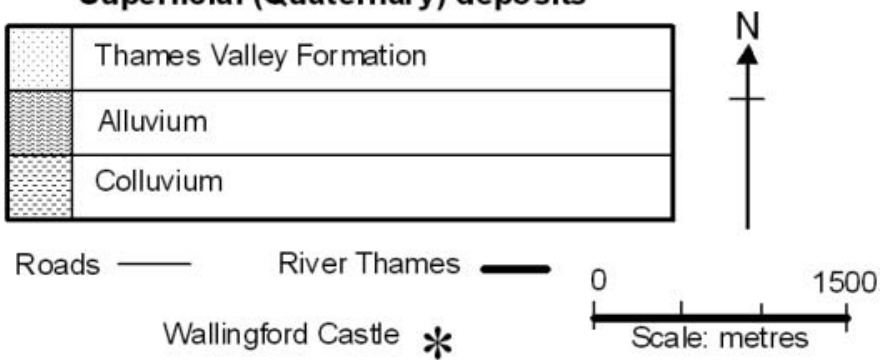

Fig. 4. Geological sketch map of the Wallingford area, south Oxfordshire. Left map shows solid geology. Right map shows the solid and drift geology. In the figure the key to the Cretaceous lithostratigraphical units is shown bottom left, with the associated chronostratigraphy (Albian, Cenomanian series etc.). Quaternary ('drift') lithostratigraphical units are shown bottom right.

\section{Ostracods}

Bairdoppilata pseudoseptentrionalis Mertens, 1956 Cornicythereis larivourensis Damotte \& Grosdidier, 1963 Cythereis hirsuta Damotte \& Grosdidier, 1963

Cythereis (Rehacythereis) luermannae luermannae (Triebel, 1940) Cythereis thoernensis Triebel, 1940

Cytherella ovata (Roemer, 1840)

Homocythere harrisiana (Jones, 1870)

Neocythere steghausi (Mertens, 1956)

Neocythere vanveenae Mertens, 1956

Protocythere lineata striata Gründel, 1966

Pterygocythereis sp. cf. laticristata (Bosquet, 1854)

Schuleridea jonesiana (Bosquet, 1852)

\section{Foraminifera}

Bulbophragmium aequale cf. aequale (Reuss, 1860)

Flourensina intermedia ten Dam, 1950

Gavelinella baltica Brotzen, 1942

Gavelinella cenomanica (Brotzen, 1942)

Gavelinella intermedia (Berthelin, 1880)

Hagenowina advena (Cushman, 1936)

Hagenowina anglica (Cushman, 1936)

Hedbergella delrioensis (Carsey, 1926)

Lenticulina rotulata Lamarck, 1804

Marginulina sp.

Marssonella ozawai Cushman, 1936

\section{Ramulina sp.}

Tritaxia macfadyeni Cushman, 1936

Tritaxia pyramidata Reuss, 1863

Tristix sp.

Vaginulina cf. mediocarinata ten Dam, 1950

\section{REFERENCES}

Airs, M., Rodwell, K. \& Turner, H. 1975. Wallingford. In: Rodwell, K. (Ed.), Historic Towns in Oxfordshire: A Survey of the New County. Oxfordshire Archaeological Unit, Oxford, 155-162.

Cappers, R.T.J., Bekker, R.M. \& Jans, J.E.A. 2006. Digitale Zadenatlas van Nederland/Digital Seed Atlas of the Netherlands. Barkhuis and Groningen University Library, Groningen, 502pp.

Kenward, H.K., Hall, A.R. \& Jones, A.K.G. 1980. A tested set of techniques for the extraction of plant and animal macrofossils from waterlogged archaeological deposits. Science and Archaeology, 13: 3-15. World Wide Web address: http://www.york.ac.uk/inst/chumpal/ EAU-reps/testedset.pdf

Perch-Nielsen, K. 1973. Fossil coccoliths as indicators of the origin of late Cretaceous chalk used in medieval Norwegian art. In Universitetets oldsaksamlings årbok 1970-71. Oslo, 161-169.

Quinn, P.S. \& Day, P.M. 2007. Ceramic micropalaeontology: the analysis of microfossils in ancient ceramics. Journal of Micropalaeontology, 26: 159-168.

Wilkinson, I.P., Williams, M., Young, J.R., Cook, S.R., Fulford, M.G. \& Lott, G.K. 2008. The application of microfossils in assessing the provenance of chalk used in the manufacture of Roman mosaics at Silchester. Journal of Archaeological Science, 35: 2415-2422. 